\title{
Preserving Traditional Food from West Java: An Effort to Maintain National and Regional Food Security
}

\author{
Rosaria Mita Amalia ${ }^{1 *}$, Davidescu Christiana Victoria Marta ${ }^{2}$ \\ Department of Linguistics/Faculty of Cultural Sciences/Universitas Padjadjaran, Jl. Raya Bandung-Sumedang \\ Km. 21 West-Java, Indonesia
}

*Corresponding Author: Rosaria Mita Amalia, Department of Linguistics/Faculty of Cultural Sciences/Universitas Padjadjaran, Jl. Raya Bandung-Sumedang Km. 21 West-Java, Indonesia

\begin{abstract}
Indonesia is the largest archipelagic country in the world with a total of 17,054 islands. Each island has different customs, values and habits. As one of the elements of culture, Indonesian culinary is also a pride cultural element.From 17,054 islands that make up the Indonesian archipelago, there is the island of Java which is known for its unique history and its beauty. It is named West Java.In Indonesia, there are many kinds of traditional food. West Java culinary can be used as one form of strength of the Indonesian nation. West Java local culinary topics became the topics raised because local gastronomy of West Java which is the heritage of ancestors is an asset of the nation that must continue to be preserved and introduced furthermore. Traditional Sundanese cuisine has to defend itself from the fast food strikes that now dominate Indonesian culinary, as well as the flow of globalization that removes the borders of the country due to the sophistication of technology and information.

Food security is a flexible concept as reflected in the many attempts at definition in research and policy usage. The writers adopt the definition of food security from The State of Food Insecurity 2001 (http://www.fao.org/docrep/005/y4671e/y4671e06.htm) which states "Food security [is] a situation that exists when all people, at all times, have physical, social and economic access to sufficient, safe and nutritious food that meets their dietary needs and food preferences for an active and healthy life". The research applies descriptive-qualitative research method and focuses on typical food of West Java as object of the research. The writers regard preserving kinds of traditional food in West Java is one of attempt to maintain not only national but also regional food security. Because in traditional food, we can find local wisdom and culinary philosophy which are the element of cultural identity of the nation.
\end{abstract}

Keywords: Culinary, Food Security, Sundanese Cuisine, Traditional Food, West Java.

\section{INTRODUCTION}

West Java Province is one of the provinces that attract attention besides having a dense population, the province has a moderate climate and extraordinary natural wealth. With a tremendous natural wealth, one form of cultural product that is interesting to be introduced from the Province of West Java is food. Food has an important role in cultured life. Food is not only as a means of fulfilling energy needs, food has economic value as well as cultural value (Amalia, 2016).

Sundanese people, it is a name for native people from West Java, by utilizing the existing ingredients in the surrounding likes to create a unique food in terms of names and flavors, name them colenak, combro, burayot, batagor, cireng, cimol, gehu, and so on. Food has an important role in the life of the Sundanese people. Traditional Sundanese cuisine has to defend itself from the fast food strikes that now dominate Indonesian culinary, as well as the flow of globalization that removes the borders of the country due to the sophistication of technology and information. During this time, West Java is famous for various types of food either in the form of snacks, drinks, and heavy foods that have become a pride for the people of West Java and the penchant for people who come from other regions. Sundanese culinary has become an icon of pride in tourism programs that highlight the authenticity of West Java (Amalia, 2016:128).

This paper explains about the result of the research through Academic Leadership Grant (ALG), a research scheme funded by Universitas Padjadjaran. The goal of the research is producing the culinary 
map of West Java. The culinary map is an attempt to preserve the traditional food in West Java. The society, especially the young generation needs to be introduced by the traditional food. Through the food, they will know about the local culture and strong philosophy from the food. Not only for young generation in West Java or Indonesia, the culinary map can be a media to promote this traditional food to the world.

West Java culinary icon can be used as one form of strength of the Indonesian nation through soft diplomacy which is part of the power of a country in the arena of other nations, because in the concept of soft power diplomacy, culture is the main topic. Food has become an integral part of the international relations policy of many countries to establish and solidify diplomatic relations, create cross-cultural understanding until a gastronomic approach to diplomacy (Amalia, 2017).

West Java local culinary topics became the topics raised because (1) local gastronomy of West Java which is the heritage of ancestors is an asset of the nation that must continue to be preserved and introduced furthermore, (2) West Java gastronomy is not merely a collection of recipes, and heritage of the nation's cultural heritage which has appeal and also has a certain meaning that has not been understood by the public in general, so ethnolinguistic research of the names of Sundanese cuisine becomes an important thing to do, (3) this research in accordance with the vision and mission of West Java Province that brings local excellence area through the gastronomy of West Java, (4) Preserving Sundanese culinary is attempt to strengthen food security in West Java and also Indonesia.

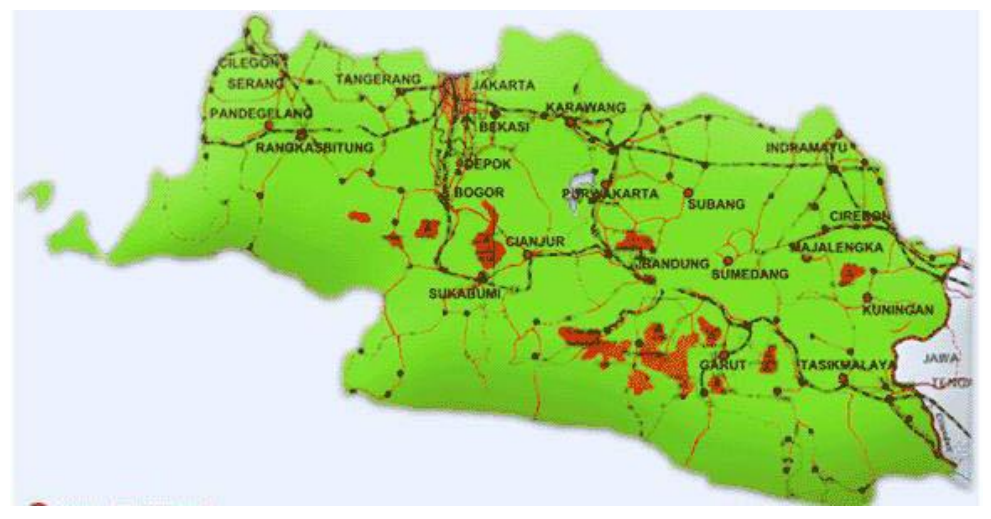

Picture1. Map of West Java

Photo credit: https://www.google.co.id/search?biw=1366\&bih=659\&tbm=isch\&sa=1\&q=peta+jawa+barat

\section{Methodology}

This research uses research method called descriptive-qualitative research method. Descriptivequalitative research method is a research method that aims to describe the things that become the object of research in gambling, this is in accordance with the definition of descriptive research methods of Djajasudarma (2000: 9) descriptive-qualitative research method aims to create a description or systemic, and accurate data, properties, and relationships of the phenomena studied. In this study, the object of the research data is the typical food of West Java which is located in big cities in West Java, such as in Sumedang and Garut.

The data are obtained by conducting survey method and questionnaire interview. The researchers go to the area to capture the culinary trademarks in some areas in West Java. Then the researchers have the instrument of questionnaire-interview sheet to give to the owner from the food brand. Furthermore, recording technique is also used in this study (Mahsun, 2005: 92-103).

Descriptive research method that has been described above, generally has an inductive research model (Chaedar, 2002: 119), in order of:

- Gathering information,

- Asking questions

- Build categories

- Looking for patterns (theory)

- Build a theory or compare patterns with other theories 
The first task is finding information about the typical foods of West Java located in the big cities in West Java that can be promoted internationally. The cities we visited are Sumedang, Garut, Kuningan, Cirebon, Cianjur, Sukabumi and Bogor. The researchers inventoried the names of the food and the area of the food maker. Then the researchers began to conduct field research, questions were made and intended for the food maker, and the originator or creator of the food. Then the food is divided into several categories, and documented. On the next stage, researcher looked for patterns or theories to preserve and promote these foods, for example by promoting its delicacy, nutritional content, and ease in the way it is made. Furthermore, researcher began to develop patterns or good theories to preserve and promote food typical of West Java.

\section{LITERATURE REVIEW}

\subsection{Ethnolinguistics}

One branch of science that can be used in the study of identity in the culture of society is ethnolinguistics as a science that examines the relationship between language with society and culture. As Philip Riley notes, the area of ethnolinguistic study involves studying the relationship between language and culture, communication practice, and the cognitive model of language and community thinking. Ethnolinguistics tries to describe and understand the role of language in shaping the way members of society relate to the world, between themselves and others. "Ways of knowing and being" in society, is the thing that constructs identity (Riley, 2007: 11).

This research uses ethnolinguistic approach as grand theory, because the culinary mapping based on geographical is very closely related to the culture of the local population. Ethnolinguistics has variously been approached as study group's experience of life and it is organized and expressed through the group's language tools and as a science whose aim is to examine the relationship between a language on the one hand and society and culture on the other (Riley, 2007:8).

\subsection{Local Wisdom and Culinary Philosophy of West Java}

Indonesia has various cultural heritages. Culinary heritage as a form of local wisdom is one of the constituents of identity and cultural identity of the nation. Therefore, the culinary diversity of the archipelago needs to be introduced, not only to the domestic community itself, but also to the international community. Sundanese culture has certain characteristics that distinguish it from other cultures. In general, the people of West Java or Tatar Sunda, known as a society that is soft, religious, and very spiritual. This tendency appears as in the pamphlets of compassion, silihand silihasuh; Loving each other (giving priority to compassion), mutual perfecting or improving (through education and sharing knowledge), and protecting each other (keeping each other safe).

Sundanese cuisine in ancient times turned out to have a dominant spicy flavor. Almost in every vegetable dish or processed meat, parents always use chili as a spice. Even if you do not use spicy seasoning, there must be chili sauce served with fresh lalaban (fresh vegetable). In the culinary treasure of Parahyangan itself, sambal can reach dozens of varieties. The variety of sambal includessambalcombrang, sambaltarasi, sambalcibiuk, sambal plow, peanut sauce, and sambalhejo.

\subsection{Soft Power Diplomacy (Cultural Diplomacy)}

The term soft power diplomacy became known in the late 1980s. The concept of contrast with hard power diplomacy was introduced by Joseph Nye from Harvard University. Soft power diplomacy is defined as the ability to get what you want through attraction rather than coercion or payment which includes culture, values, and foreign policies (Nye, 2004: 11). West Java culinary icon can be used as one form of strength of the Indonesian nation through soft diplomacy which is part of the power of a country in the arena of other nations, because in the concept of soft power diplomacy, culture is the main topic.

Food has become an integral part of the international relations policy of many countries to establish and solidify diplomatic relations, create cross-cultural understanding until a gastronomic approach to diplomacy emerges. The origin of raw materials and natural factors is taken into consideration, manufacturing techniques and presentation are taken into account, historical background is recorded, quality and nutrition take precedence, and most importantly the elegant taste is emphasized for the truth and goodness of a food. That is the meaning of gastronomy that does distinguish it from the 
meaning of the word culinary, which is limited only in cooking techniques only. With its diversity of food, Indonesia has tremendous potential to apply the gastronomic diplomacy strategy with a specialization of introducing West Java culinary as one of Indonesian culinary icons.

\subsection{Food Security in West Java}

The State of Food Insecurity 2001 (http://www.fao.org/docrep/005/y4671e/y4671e06.htm) states "Food security [is] asituation that exists when all people, at all times, have physical, social and economic access to sufficient, safe and nutritious food that meets their dietary needs and food preferences for an active and healthy life". Every country needs to guarantee the society that they can be fulfilled by the basic needs. The basic needs includes the nutritious food. Through this research, we are going to show that preserving the Sundanese culinary is one of potential attempt relating to strengthen food security in West Java. Maintaining the local or traditional food, the government needs to have good arrangement in serving the material of the food, it means the method of cultivation. For some regions, the method used by the farmers are connected to traditional knowledge. And where traditional knowledge is being revived, food security outcomes are better. Indigenous knowledge systems can be used to improve agricultural productivity and food security among rural poor communities. Indigenous knowledge is the knowledge that is unique to a given culture and provides a basis for local-level decision making in agriculture, health care, food preparation, education, naturalresource management, and a host of other activities in rural communities (Warren 1991, Flavier et al 1995, Kolawole, 2001, Maikhuri, et al, 1999). Unfortunately, this knowledge is usually not taken seriously as a viable alternative for ensuring food security and nutrition (http://www. abc.net.au/news/rural/2015-10-12/traditional-knowledge-the-key-to-food-security/6846026)

\section{RESUlT AND DisCUSSION}

This research has been conducted for two (2) years, in the last two years, the researchers have collected data from some big areas in West Java, namely Sumedang, Garut, Kuningan, Cirebon, Subang, Purwakarta, and Bogor. We went to the traditional food seller in that area, having some interview and questionnaire about the ingredients, we have made culinary map of West Java from that area. Another purpose of this research is finding iconic food from West Java which really represents West Java to the world. The mapping of West Java culinary is useful to introduce kinds of traditional food from West Java to the visitors and to young generation. We are quite worried about the condition now days because most of the young generation in West Java especially in some big cities prefer choosing Western food compare to traditional food. We would like to introduce, promote and preserve the traditional knowledge and kinds of food as a symbol of the productivity of West Java culture.

Some efforts conducted are presenting the result of this research in some international conferences in Indonesia and also abroad. The topic discussed are,

- Ethno linguistic Study on Culinary Trademark in West Java, Indonesia, presented at GCSS International Conference, Bangkok, Thailand in March 2016.

- Globalization of Local Cuisine in West Java:An Attempt to Introduce and Preserve the Cuisine through Cultural Diplomacy, presented at ICLEI International Conference, Ho Chi Minh, Vietnam in May 2017.

- Cultural Translation of Traditional Food from West-Java: A Media to Promote the Traditional Cuisine to the Word, presented at LAMAS International Conference, Semarang, Indonesia in August, 2017.

- Globalization of Traditional Culinary of West- Java as Soft Power Diplomacy Instrument, presented at International Seminar on Nusantara Heritage, Bali, Indonesia in September 2017.

When we presented the paper, the audience gave us good feedback in developing this research specifically for preserving traditional food from West Java then introduce them to the world. Another effort conducted was having culinary festival from foreign/international students in Universitas Padjadjaran. Types of food served at this culinary festival are Soto Ojolali from Bandung, Soto Ahri from Garut, EmpalGentong from Cirebon, and Soto Bongko from Sumedang. Selection of soto-sotoan type based on the idea that almost in every region in West Java have typical food in the form of soup 
and the researcher concluded that this type of food has a taste that can be accepted by the tongue of foreign visitors. The respondents in this activity are foreign students who are pursuing their education in Universitas Padjadjaran (Unpad). The number of participants is 26 students from Turkey, India, Tanzania, Sudan, Nigeria, Vietnam, Thailand, Madagascar, Korea, China and Japan. The diversity of countries is expected to provide much input on the selection of traditional West Java food types that the taste is acceptable to foreign visitors (Amalia, 2017:595).

Finally, we can suggest that the things to do for local food security are;

\subsection{Mapping the Traditional Foods in West Java.}

The map of traditional foods in West Java is important to know the resource of this matter. By having this information, we can know the riches from this sector and it can be developed into so many sectors.

\subsection{Create Traditional Food Brochures in Various Foreign Languages.}

We are now in the process of creating good and interesting West Java culinary brochures or catalogue. It will be created into 6 languages that are Indonesia, Russian, Arabic, Japanese, French, and English. The purpose of writing the information in some languages regarding to have more attraction from people abroad. The media can be potential tools in promoting West Java culinary tourism.

\subsection{Collaboration among Chef in West Java to Make Various Modifications to Traditional Food of West Java}

The modification in ingredients and packaging to traditional food must be needed to adjust the abroad market and young people generation. By this process, the collaboration among chef and culinary expert has been waiting to develop the authentic and modern menu.

\subsection{Conducting Promotion in Various Media about the Uniqueness and Excellence of Food Types in West Java}

Doing promotion through digital media especially in social media in this era can spread the information fast and easily. The content of promotion of this traditional food needs to be regenerated. The content should relate to the visual and attractive content.

\subsection{Making various Regulations Related to the Efforts of Defense and Development of Traditional Food of West Java}

The local government side and support are needed to realize this purpose. The government can give policy in purpose to increasing local product quality by giving intensive training about how to develop the packaging of the food, how to make creative content of promotion, how to create attractive tagline for the product and many more.

\subsection{Conduct an In-Depth Study of the Benefits of Traditional Food from West Java}

The researchers and expert culinary needs to discover inform more to society about the benefit of traditional food. One of specific traditional food from West Java is vegetables. Sundanese people love to consume some kinds of fresh vegetables and they eat the vegetables with sambel (traditional sauce consisting of fresh chilly). The vegetables with the sauce are full of many vitamins and it can make healthy our body.

\subsection{Developing and Preserving Indigenous Knowledge Systems because the Attempt can be Used to Improve Agricultural Productivity and Food Security.}

The agricultural indigenous system of Sundanese people needs to be develop and preserve. The Sundenese people have their indigenous knowledge in agriculture, they name it tandur/tanammundur. Tandur is a way of planting rice in paddy fields with wetlands or irrigated rice fields. The preserving of agricultural system can maintain the food security in West Java.

\section{CONCLUSION}

There should be serious and continuous effort in preserving traditional food from West Java. It relates to agricultural productivity and food security. In traditional food, there are some indigenous knowledge and local philosophy which must be introduced to young generation. The government 
needs to support this activity because they can get plenty of benefit, one of them is developing culinary tourism. It will create economic development for the people in West Java. By having the culinary mapping of West-Java traditional food, the government can use the information as the basis of making policy relating to defense food security for the people. And the government can use this as a media of promotion to the world in effort to globalize traditional culinary of West Java as soft power diplomacy instrument.

\section{RECOMMENDATION}

The result can be a recommendation for the stake holders and West Java government in how they preserve indigenous knowledge to defense food security and also can take it as benefit to develop culinary tourism in West Java.

This research is supported by a grant from Universitas Padjadjaran in Academic Leadership Grant (ALG) Scheme.

\section{REFERENCES}

[1] Amalia, Rosaria Mita. 2016. Ethno linguistic Study on Culinary Trademark in West Java, Indonesia. Conference Proceeding of Global Conference on Social Science (GCSS) ISBN Number 978-986 565440 5 (page127-133), Bangkok, Thailand.

[2] Amalia, Rosaria Mita. 2017. Globalization of Local Cuisine in West Java: An Attempt to Introduce and Preserve the Cuisine through Cultural Diplomacy, Conference Proceeding ISBN Number 978-967-144678-2 (page 109-115) Ho Chi Minh,Vietnam.https://proceedings.icsai.org/7iclei/7iclei-068.pdf

[3] Amalia, Rosaria Mita. 2017. Globalization of Traditional Culinary of West Java as Soft Power Diplomacy Instrument. Conference Proceeding of Internatipnal Seminar on Nusantara Heritage (ISONHA) 2017. ISBN Number 978-602-9164-17-6 (page 593-596)

[4] Djajasudarma, Fatimah. 2006. MetodeLinguistik: AncanganMetodePenelitiandanKajian. Bandung: RefikaAditama.

[5] Endraswara, Suwardi. 2006. MetodologiPenelitianKebudayaan. Yogyakarta: GadjahMada University Press.

[6] Melissen, Jan. (2005).The New Public Diplomacy. New York: Palgrave Macmillan.

[7] Nye, Jr.,Joseph. (2004) "Soft Power: The Means to Success in World Politics" New York Public Affairs.

[8] Philip Riley 2007 Language, Culture and ldentity:An Ethnolinguistic Perspective. British Library London: Continum Sugiyono, D. (2000). Metode Penelitian. Bandung: CV Alvabeta.

[9] https://www.google.co.id/search?biw=1366\&bih=659\&tbm=isch\&sa=1\&q=peta+jawa+barat (accessed Ma y $1^{\text {st }}, 2017$ )

[10] http://www.fao.org/fsnforum/sites/default/files/files/90_indigenous_knowledge/summary_89_EN_indigen ous_methods.pdf (accessed, November 10th, 2017)

[11] http://www.fao.org/fsnforum/activities/discussions/indigenous-methods (accessed, November 10th, 2017)

[12] http://www.abc.net.au/news/rural/2015-10-12/traditional-knowledge-the-key-to-food-security/6846026 (accessed, November 10th, 2017)

\section{AUTHOR'S BIOGRAPHY}

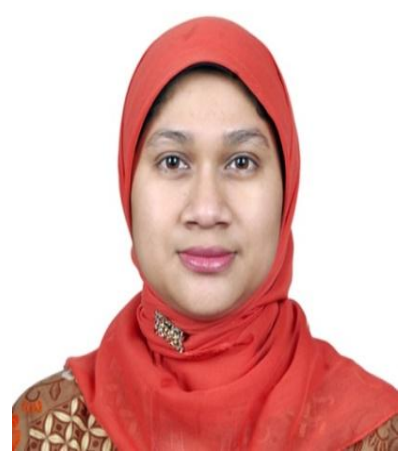

Dr. Rosaria MitaAmalia is a senior lecturer from English Literature, Faculty of Cultural Sciences, Universitas Padjadjaran. She is also recognized as a member of Department of Linguistics. Her research interests lie in the area of Pragmatics, (Critical) Discourse Analysis, Language and Diplomacy and Culture, ranging from theory to design to implementation. Her current research are about Indonesian Diplomacy Strategy through Politeness of Language between Indonesia and Australia which is supported by Universitas Padjadjaran in Riset Fundamental Unpad scheme and Globalization of West Java Cuisine through Soft Power Diplomacy funded by Universitas Padjadjaran through Academic Leadership Grant scheme. She also writes student and teacher English books for deaf students grade 10 with the title Speak up Your Mind in English. The writing of the books are supported by Indonesian Ministry of Education and Culture and can be downloaded at http://bse.kemdikbud.go.id. 

Security

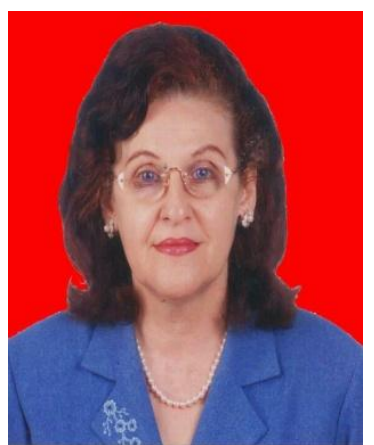

Professor.Dr. Davidescu Cristiana Victoria Marta, MA is a professor of Linguistics in Department of Linguistics in Universitas Padjadjaran. She is a professor in Syntax and Semantics. She was awardee from Fulbright Scholarship for research on Problem Based Learning as a Successful Methodology in Teaching Learning Process, Cornell University, Ithaca, NY, USA in 2010. Her publication lie in books, national and international journals, and international proceedings. Some of her publications are 'Collaborative Learning in Foreign Languages Classes' (Journal of Modern Linguistics, 2012), 'Implementation of Sundanese Leadership Values In Educational Management : A Study on "Dasa Pasanta" in School Principal Leadership Based on Sundanese Cultural Values of Leadership'( International Journal of Education, 2013) ,' A reconstruction of Racist Ideology in Richard Wright's Native Son(IOSR Journal of Humanities and Social Sciences, vol.19, Issue 3, March 2014', and 'The dative case in Russian and its meaning in Indonesian’ (National Accredited Journal Metalingua, 2015).

Citation: Rosaria Mita Amalia, Davidescu Christiana Victoria Marta. "Preserving Traditional Food from West Java: An Effort to Maintain National and Regional Food Security". International Journal on Studies in English Language and Literature (IJSELL), vol 6, no. 9, 2018, pp. 1-7. doi:http://dx.doi.org/10.20431/23473134.0609001.

Copyright: () 2018 Authors. This is an open-access article distributed under the terms of the Creative Commons Attribution License, which permits unrestricted use, distribution, and reproduction in any medium, provided the original author and source are credited. 